\title{
Spinal Fluid Collection Technique from the Atlanto-occipital Space in Pigs
}

\author{
Antonio D’Angelo', Claudio Bellino', Barbara Miniscalco ${ }^{1}$, Maria Teresa Capucchio², \\ Cristina Biolatti ${ }^{1}$, Aurelio Cagnasso ${ }^{1}$ \\ ${ }^{1}$ Department of Animal Pathology - Clinical Section, ${ }^{2}$ Department of Animal Pathology - Pathology Section, \\ University of Turin, Grugliasco, Italy
}

Received April 3, 2008

Accepted February 9, 2009

\begin{abstract}
Cerebrospinal fluid (CSF) analysis has an important role in the diagnosis of neurologic diseases. A technique for collecting CSF from the atlanto-occipital space in 20 pigs (body mass $150-160 \mathrm{~kg}$ ) is described and the CSF values are reported. CSF was relatively easily collected from the cerebellomedullary space in all animals. The protein concentration and total cell count of CFS samples ranged from 20 to $32 \mathrm{mg} / \mathrm{dl}$ and from 2 to 15 cells/ $\mu 1$, respectively. Mononuclear cells were the predominant cellular type; a variable proportion of two different cell populations (monocytoid cells and lymphocytes) was observed.
\end{abstract}

Swine, neurology, cerebrospinal fluid analysis, atlanto-occipital punction, collection technique

Although neurologic diseases in pigs are often encountered, physical examination is seldom performed. Necropsy of the affected animals is an irreplaceable tool to establish a diagnosis, however, lesions are not always easy to detect at gross anatomy and histology/ immunohistochemical analysis for identifying the disease is both time consuming and costly (Dewey 1999).

Cerebrospinal fluid (CSF) analysis plays an important role in the diagnosis of neurologic diseases, especially in detecting inflammatory pathologies. Total cell count and microprotein concentration can provide useful information for differentiating between inflammatory, neoplastic and degenerative processes. Moreover, differential cell count and cellular morphology can aid in further defining the pathological process (Lorenz 2004). For these reasons, CSF collection should be part of the diagnostic work-up so that therapeutic strategies can be undertaken while awaiting further investigations.

Few studies have reported on CSF collection and analysis in swine (Fankhauser 1962; Ebeid et al. 1997; Bailey and Vernau 1997). CSF collection from the lumbosacral space was shown to be easily accomplished and to avert the potential complication of needle penetration of the brain stem encountered with the atlanto-occipital approach (Ebeid et al. 1997).

Several factors argue for the use of the atlanto-occipital approach, nonetheless: CSF collection is more likely to be abnormal or representative of the central nervous system (CNS) diseases when performed caudal to the lesion; general anaesthesia is indispensable for this procedure in swine, except in moribund animals (Fankhauser 1962); occipital bone conformation in swine allows access to the atlanto-occipital space without flexing the neck or intubating the patient (Plate XV, Fig. 1) (Barone 1980). This study describes how we performed CSF collection at the atlanto-occipital space in 20 pigs and reports the results of CSF analysis.

\section{Materials and Methods}

Animals

The study population was 20 swine (Landrace $\times$ Large White), nine months old, body mass $150-160 \mathrm{~kg}, 10$ males and 10 females. Clinical examination was performed to rule out symptoms of clinically manifest disease.

Address for correspondence:

Prof. A. D'Angelo, DVM, PhD, Dip. ECVN, Dip. ECBHM

Department of Animal Patology

University of Turin

Via L. Da Vinci 44, 10095 Grugliasco (TO), Italy
Phone: +39 011-6709076

Fax: +39 011-6709083

E-mail: antonio.dangelo@unito.it

http://www.vfu.cz/acta-vet/actavet.htm 
The animals constituted the control group of a government-approved experimental project in which CSF tapping was included to evaluate drug carriage across the blood-brain barrier.

The study was performed according to animal welfare considerations and regulations. The protocol used in this experiment complied with the guidelines of the Italian Ministry of Health.

Cerebrospinal fluid collection

General anaesthesia was induced by intramuscular injection of tiletamine-zolazepam (Zoletil ${ }^{\circledR}$, Virbac, Milan Italy) at a dose of $4.0 \mathrm{mg} / \mathrm{kg}$ and xilazine (Rompum ${ }^{\circledR}$, Bayer HealthCare LLC, Shawnee Mission, KS, USA) at a dose of $2.0 \mathrm{mg} / \mathrm{kg}$.

CSF collection was performed with the patient in lateral recumbency (right side) with the dorsum near the table edge. The snout was elevated to place the sagittal plane of the muzzle parallel to the table. The neck was not flexed (Plate XV, Fig. 2). The collection site $(5 \times 10 \mathrm{~cm})$ was clipped and surgically prepared. Disposable $18 \mathrm{G} \times 6$ inch

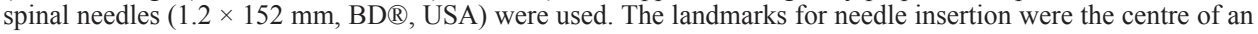
imaginary line connecting the caudal ear margins and the occipital protuberance. The left thumb (right-handed examiner) was placed on the occipital protuberance at the midline and then moved 7-10 mm caudally. The needle was positioned just cranially to the finger and directed perpendicular to the neck (Plate XVI, Fig. 3a, 3b). After the needle had penetrated for $4-5 \mathrm{~cm}$, the stylet was removed. CSF appeared in the hub of the needle immediately after it entered the subarachnoid space and was collected into a collection tube $(5 \mathrm{ml})$. If the needle hit bone while being advanced, it was removed and collection was attempted again slightly more caudal. A light pop could occasionally be felt as the needle advanced through meninges.

Cerebrospinal fluid analysis

CSF samples were analyzed within $0.5 \mathrm{~h}$ after collection. To asses total nucleated cell count, $100 \mu \mathrm{l}$ of CSF were added to $100 \mu \mathrm{l}$ of Turk's stain and placed on a Nageotte haemocytometer. This was done by dividing the number of cells counted in 8 rectangle divided for 10 .

Two slides for differential cell count and morphologic evaluation were prepared by cytocentrifugation (Cytospin2, Shandon, Pittsburgh, PA, USA) of $250 \mu \mathrm{l}$ of CSF for $6 \mathrm{~min}$ at $150 \mathrm{~g}$, and stained with MayGrünwald Giemsa. Only samples with at least 100 cells per slide were utilized for the differential cell count. Cell types, expressed in per cent, were neutrophils, eosinophils, basophils and mononuclear cells subdivided into lymphocytes, morphologically similar to those in peripheral blood, and monocytoid cells, large mononuclear cells with an abundant, pale, often finely foamy cytoplasm and a round to ameboid nucleus (Plate XVII, Fig. 4) (Freeman and Raskin 2001).

Total microprotein concentration was measured by the spectrophotometer method (Sentinel Diagnostics, Sentinel Ch. S.p.A, Milan, Italy) using a pyrogallol red microprotein assay.

Necropsy

All animals were euthanized with a lethal injection of Thiopental (Pentothal Sodium ${ }^{\circledR}$, Intervet Italia S.r.l., Milan Italy. Gross and histological examination of the brain was performed to exclude the presence of lesions.

Table 1. CSF findings (range) in 20 healthy pigs

\begin{tabular}{|l|c|}
\hline & $\begin{array}{c}\text { Mean } \pm \text { SD } \\
\text { (range) }\end{array}$ \\
\hline Protein- mg/dl & $\begin{array}{c}25.60 \pm 3.00 \\
(20-32)\end{array}$ \\
\hline Cells count / $\mathrm{ll}$ & $\begin{array}{c}5.60 \pm 3.86 \\
(2-15)\end{array}$ \\
\hline Mononuclear - \% & $\begin{array}{c}97.95 \pm 5.47 \\
(46-100)\end{array}$ \\
\hline Monocytoides - \% & $\begin{array}{c}77.30 \pm 15.91 \\
(46-99)\end{array}$ \\
\hline Lymphocytes - \% & $\begin{array}{c}20.80 \pm 14.18 \\
(1-43)\end{array}$ \\
\hline Neutrophils - \% & $\begin{array}{c}1.90 \pm 5.43 \\
(0-24)\end{array}$ \\
\hline Eosinophils - \% & $\begin{array}{c}0.10 \pm 0.30 \\
(0-1)\end{array}$ \\
\hline Basophils - \% & $\begin{array}{c}0.05 \pm 0.22 \\
(0-1)\end{array}$ \\
\hline
\end{tabular}

Plus-minus vales are the mean $\pm \mathrm{SD}$
Data recording and analysis

Data analysis was performed using a freeware statistical software package ( $\mathrm{R}$ 2.6.2). The ShapiroWilk Normality Test was applied to determine whether the data followed a normal distribution. The descriptive statistics mean \pm standard deviation (SD) and range were calculated.

\section{Results}

CSF was collected from the atlanto-occipital space in all animals. CSF gross appearance was clear, watery and colourless. CSF findings are showed in Table 1. No potential complications due to needle penetration of the brain stem were observed at necroscopy. Histological examination of the brain was normal.

\section{Discussion}

Atlanto-occipital puncture has been reported as being problematic. The preferred technique in large animals $(\geq 80 \mathrm{~kg})$ is 
lumbosacral puncture (Fankhauser 1962; Ebeid et al. 1997). However, with practice on dead swine we managed to achieve confidence and accuracy with the atlanto-occipital approach, so that CSF could be relatively easily collected from the cerebellomedullary space in all animals. The use of a longer needle $(152 \mathrm{~mm})$ was necessary to reach the deep lying meninges. The combination of telazol and xylazine induced a long duration of action and a good level of anaesthesia.

Microprotein concentration and differential cell count values were comparable to published data (Fankhauser 1962; Bailey and Vernau 1997). Fankhauser reported a total cell count of 0-7 cells/ml. Microprotein concentration in the studies by Fankhauser and Bailey and Vernau was $49 \mathrm{mg} / \mathrm{dl}$ and 24-29 mg/dl, respectively. Mononuclear cells were the predominant cellular type; a variable proportion of two different cell populations (monocytoid cells and lymphocytes) was observed. To the best of authors' knowledge there are no more precise data in literature on the amount of monocytoid cells and lymphocytes in healthy swine CSF.

CSF analysis represents an essential test in approaching a neurological patient. With regards to the field condition, CSF collection and its correct interpretation have a determining role in making differential diagnoses and therapeutic strategies. Pig shape makes singling out landmarks for an invasive procedure challenging. However, with correct head positioning (without neck flexion), precise identification of the occipital protuberance, perpendicular needle direction and adequate needle length, CSF collection via the atlanto-occipital approach is possible in pigs showing neurological symptoms, even in weighty animals.

\section{Technika odběru spinální tekutiny $\mathrm{z}$ atlantookcipitální prostoru u prasat}

Analýza cerebrospinální tekutiny (CSF) hraje důležitou roli v diagnóze neurologických onemocnění. V této práci je popsána technika odběru CSF z atlantookcipitálního prostoru u 20 prasat značné hmotnosti a jsou uvedeny naměřené hodnoty. Mozkomíšní mok byl poměrně snadno odebírán z cerebellomedulárního prostoru u všech zvířat.

\section{Acknowledgments}

The authors thank Mr. R. Mattioda, Mr. D. Palmerini and Miss M. R. Centanni from the Clinical Pathology Lab, Department of Animal Pathology, Faculty of Veterinary Medicine of Turin, for their help and expertise in technical support.

\section{References}

Bailey CS, Vernau W 1997: Cerebrospinal fluid. In: Kaneko JJ, Harvey JW, Bruss ML (Eds.): Clinical biochemistry of domestic animals. Academic Press, San Diego, pp. 785-827

Barone R 1980: Ossa della testa. In: Barone R (Ed.): Anatomia comparata dei mammiferi domestici. Vol. 1, $1^{\text {th }}$ ed. Osteologia. Edizioni Agricole, Bologna, pp. 53-103

Dewey CE 1999: Diseases of the nervous and locomotor systems. In: Straw BE, D'Allaire S, Mengeling L, TaylorDJ (Eds.): Diseases of swine. $8^{\text {th }}$ ed. Blackwell Science, Oxford, pp. 861-882

Ebeid M, Zimmermann W, Martig J 1997: Collection and diagnostic value of CSF in pigs. Large Anim Pract 18: 32-33

Fankhauser R 1962: The cerebrospinal fluid. In: Innes JRM, Saunders LZ (Eds.): Comparative neuropathology. $1^{\text {st }}$ ed. Academic Press, London, pp. 21-54

Freeman KP, Raskin RE 2001: Cytology of the central nervous system. In: Raskin RE, Meyer DJ (Eds.): Atlas of canine and feline cytology. $1^{\text {st }}$ ed. Saunders Company, Philadelphia, pp. 325-365

Lorenz MD, Kornegay JN 2004: Neurologic history and examination. In: Lorenz MD, Kornegay JN (Eds.): Handbook of veterinary neurology. $4^{\text {th }}$. WB Saunders, St. Louis, pp. 3-46

R Development core team R 2007: A language and environment for statistical computing. In: R Foundation for statistical computing. Vienna, Austria, ISBN 3-900051-07-0; http://www.r-project.org 
Plate XV

D'Angelo A. et al.: Spinal Fluid ... pp. 303-305

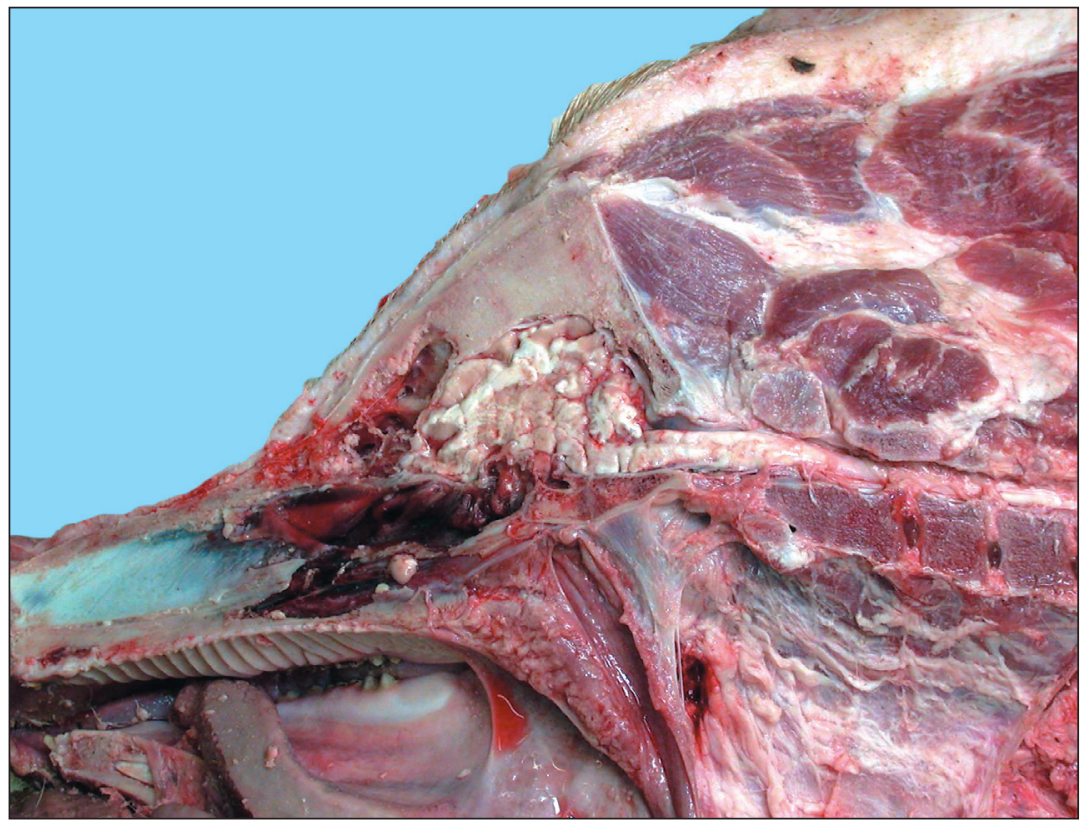

Fig. 1. Occipital bone conformation (midsaggittal view)

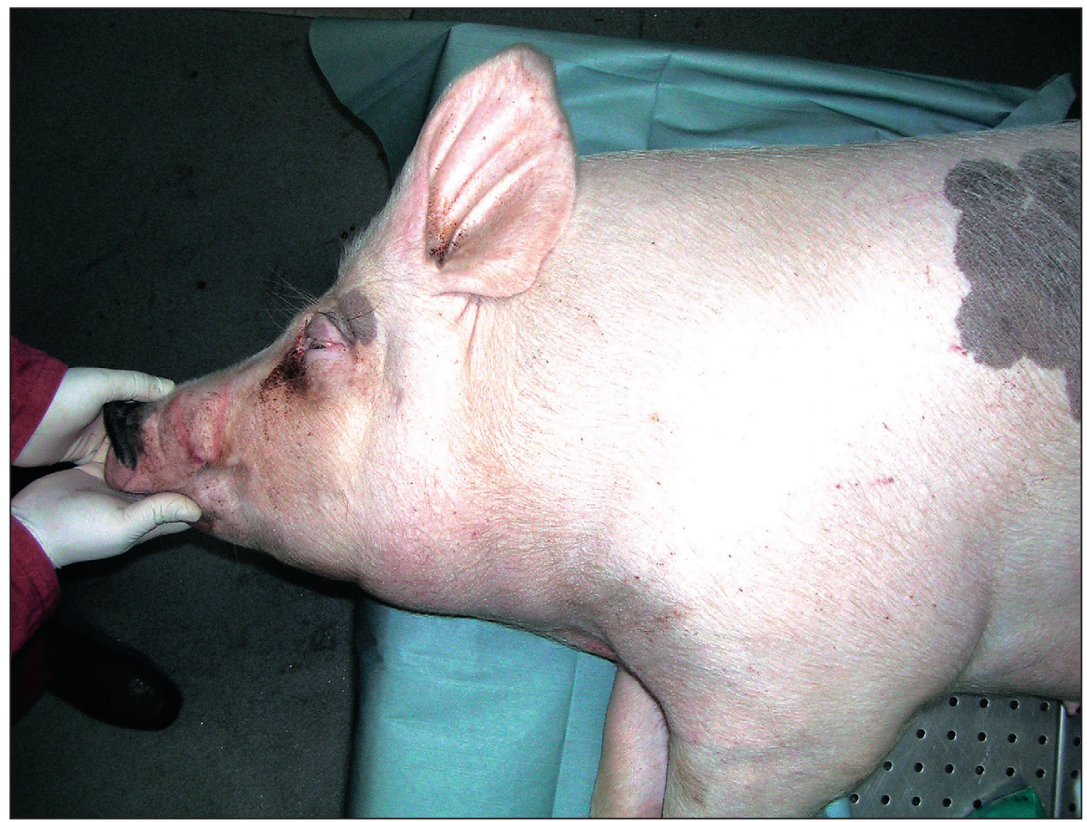

Fig. 2. Right side lateral recumbency. The snout is elevated to place the sagittal plane of the muzzle parallel to the table. 


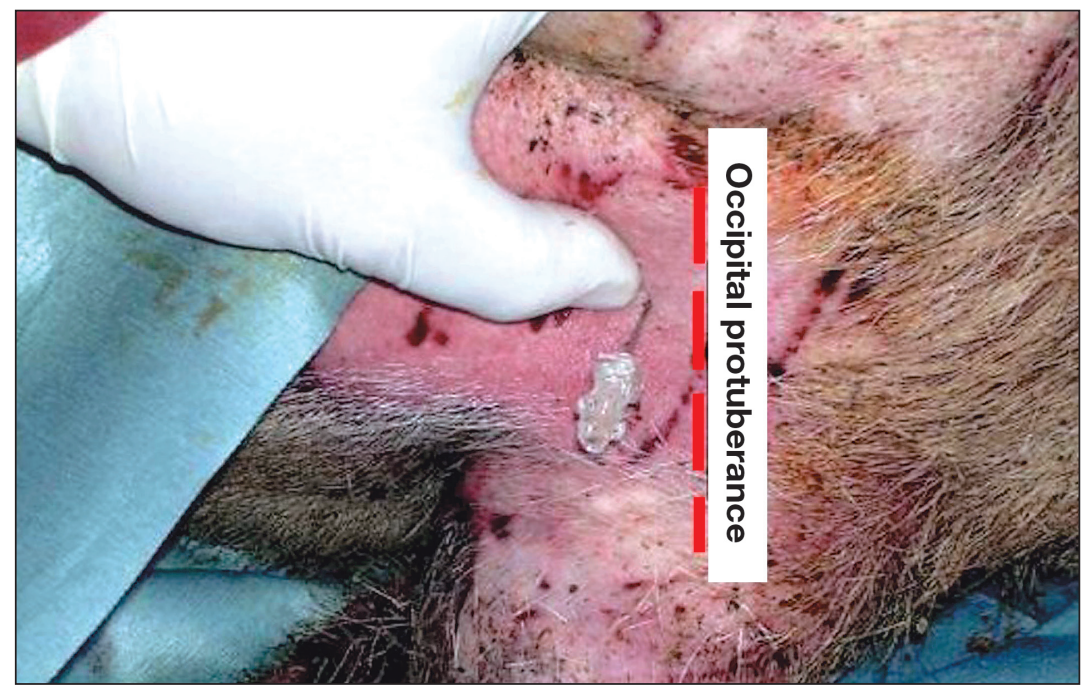

Fig. 3a. The needle is positioned just cranially to the left thumb (right-handed examiner)

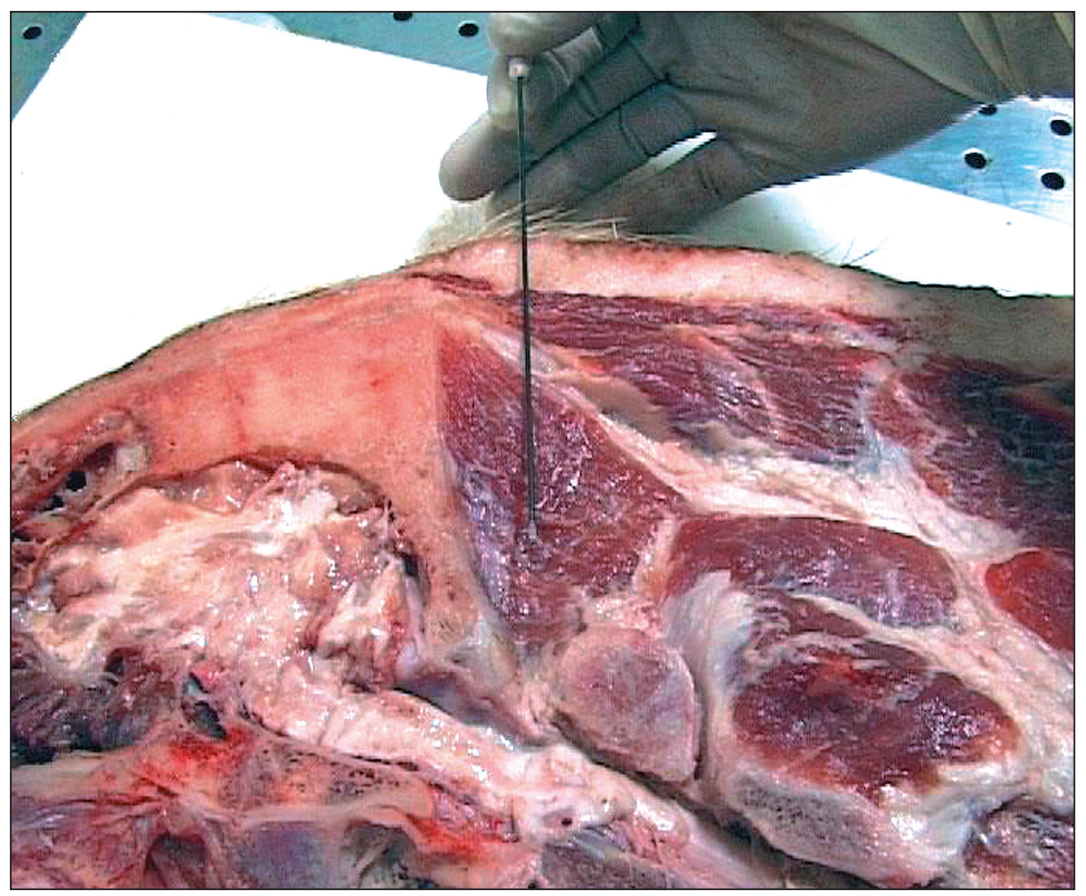

Fig. 3b. The needle is directed perpendicular to the neck deep to the meninges 


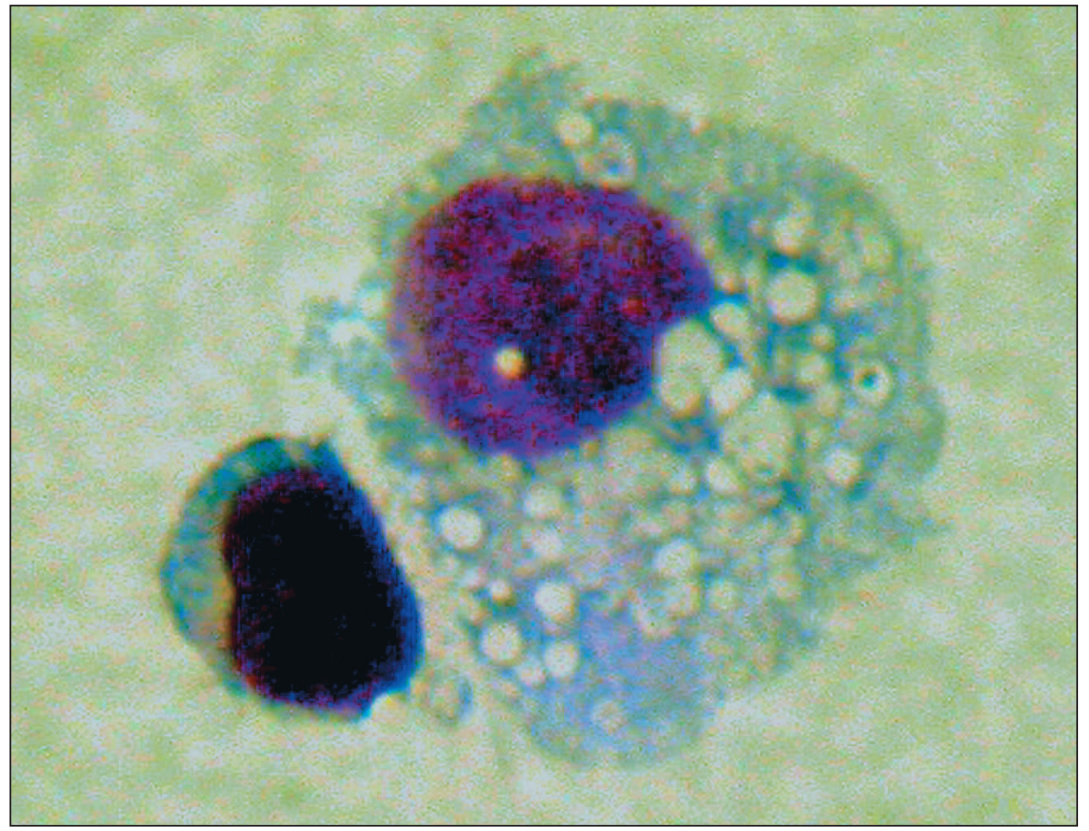

Fig. 4. Mononuclear cells in swine CSF: one large monocytoid cell (right) and one lymphocyte (left), magnification, $\times 1000$ 